\title{
Histone-Lysine N-Methyltransferase 2A
}

National Cancer Institute

\section{Source}

National Cancer Institute. Histone-Lysine N-Methyltransferase 2A. NCI Thesaurus. Code C17595.

Histone-lysine N-methyltransferase MLL (3969 aa, $432 \mathrm{kDa}$ ) is encoded by the human MLL gene. This protein is involved in both histone modification and transcriptional activation. 